\title{
Tietze Sendromu: Bir Olgu Sunumu
} Tietze's Syndrome: A Case Report

\section{Havva ÖZTÜRK DURMAZ'1, Hatice Rana ERDEM²}

\author{
Şereflikoçhisar Devlet Hastanesi, Ankara, Türkiye \\ ${ }^{2}$ Yüksek İhtisas Üniversitesi Tıp Fakültesi, Fiziksel Tıp ve Rehabilitasyon Anabilim Dalı, Ankara, Türkiye
}

öz

Tietze sendromu (TS), genellikle kostosternal, kostokondral ve sternoklaviküler eklemlerde hassasiyet, ağrı ve non-pürülanşişlik ile karakterize nadir görülen bir inflamatuvarartropatidir. Sıklıkla kostosternal eklemleri tutar ve sternoklaviküler eklem tutulumu nadirdir. Bu olgu sunumunda yaklaşık 2 yıldır göğüs ön duvarı sağ üst bölümünde ağrı ve şişlik şikayeti olan 72 yaş kadın hastayı sunuyoruz. Yapılan fizik muayenede sağ sternoklaviküler eklemde hassasiyet ve yaklaşık $2 \times 2 \mathrm{~cm}$ 'lik orta sertlikte şişlik saptandı. Şişlik olan bölgeye yapılan ultrasonik görüntülemede sağ sternoklaviküler eklem bölgesinde ekojenite artışı ve ödem saptandı. Laboratuvar bulguları normaldi. Hastaya TS tanısı kondu ve kortikosteroid ve lokal anestezik karışımından lokal enjeksiyon yapıldı. Hastanın şikayetleri infiltrasyon sonrası belirgin şekilde azaldı. Bu olgu sunumunda sternoklaviküler eklem tutumlu ve lokal enjeksiyon ile tedavi ettiğimiz TS olgusunu sunuyoruz.

Anahtar Kelimeler: Tietze sendromu, sternoklaviküler eklem, kostokondrit

\section{ABSTRACT}

Tietze syndrome (TS) is a rare inflammatory arthropathy characterized by tenderness, pain, and non-purulent swelling of the costosternal, costochondral and sternoclavicular joints. It often involves the costosternal joints and sternoclavicular jointinvolvement is rare. In this case report, we present a 72-year-old female patient suffering from pain and swelling in the right upper chest wall fo rabout 2 years. Physical examination revealed tenderness in the right sternoclavicular joint and an approximately $2 \times 2 \mathrm{~cm}$ moderate swelling. Ultrasonic imaging of the swelling area revealed increased echogenicity and edema in the right sternoclavicular joint area. Laboratory findings were normal. The patient was diagnosed with TS and a local injection of a corticosteroid and local anesthetic mixture was administered. The patient's complaints decreased significantly after the infiltration. In this case report, we present a TS case with sternoclavicular joint involvement that we treated with local injection.

Keywords: Tietze's syndrome, sternoclavicularjoint, costochondritis

\section{Giriș}

Tietze sendromu (TS), genellikle kostosternal, kostokondral ve sternoklaviküler eklemlerde hassasiyet, ağrı ve non-pürülanşişlik (\%70-80) ile karakterize, benign karakterli,nadir görülen bir inflamatuvar artropatidir (1). Kesin etiyolojisi bilinmemekle birlikte Mikrotravma Teorisi üzerinde durulmaktadır. Klinik olarak göğüs ön duvarında ağrı ve şişlik şeklinde ortaya çıkabilir. Biz bu olgu sunumunda göğüs ön duvarında ağrı ve şişlik nedeni ile polikliniğimize başvuran sternoklaviküler eklem tutulumlu bir olguyu sunarak göğüs ön duvarı ağrılı sendromlarına dikkat çekmek istiyoruz

\section{Olgu}

Fiziksel Tip ve Rehabilitasyon (FTR) Polikliniğimize başvuran 72 yaşında bayan hastanın gögüs ön duvarı sağ üst bölümünde ağrı, şişlik ve kızarıklık şikayeti mevcuttu. Hasta yaklaşı 2 yıldır bu şikayeti ile farklı polikliniklere tekrarlayan başvuruları olduğunu ifade etti. Kilo kaybına bağlı kemik çıkıntısı olabileceği söylendiğini ancak kilo kaybı olmadığını belirtti. Nonsteroidalanti inflamatuvar ilaçlar (NSAïi) kullandığını ancak faydalanmadığını belirtti. Hastanın özgeçmişinde dermatolojik ya da romatolojik başka bir hastalı̆̆ı yoktu. Yapılan fizik muayenede sağ sternoklaviküler eklemde hassasiyet ve yaklaşık $2 \times 2 \mathrm{~cm}$ 'lik orta sertlikte şişlik saptandı (Şekil 1). Sistemik muayene doğaldı. Diğer eklemlerde ağrı, hassasiyet, 


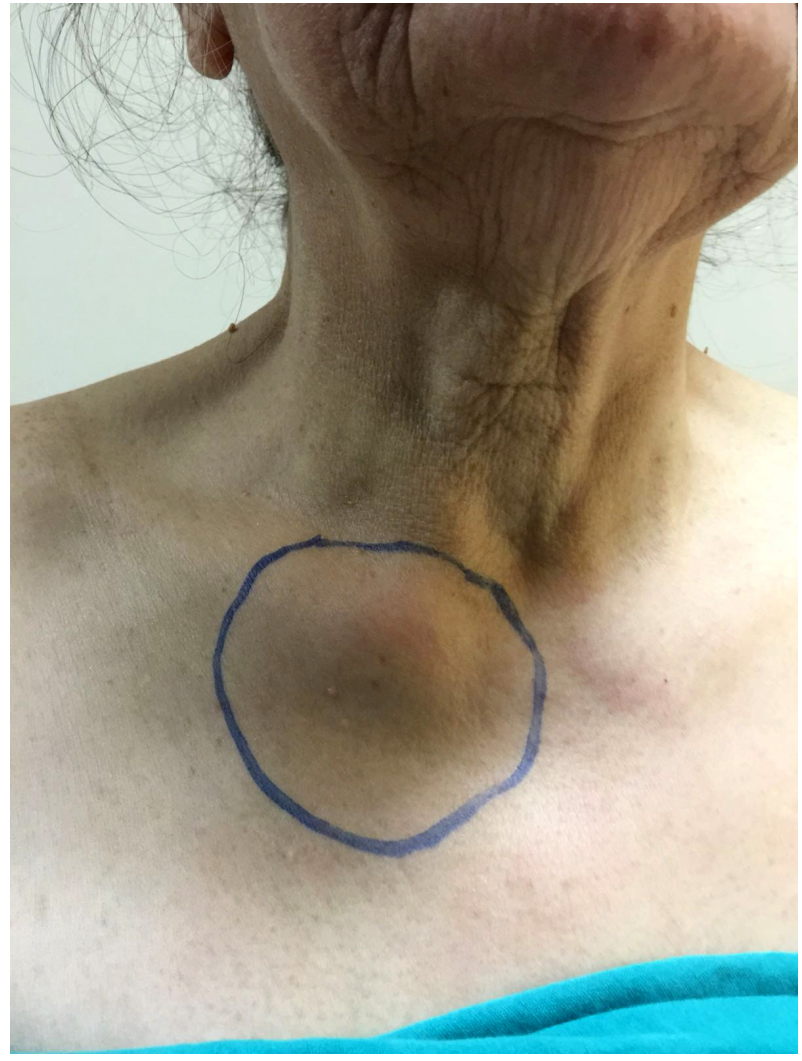

Şekil 1. Hastanın sağ sternoklaviküler bölge görünümü.

şişlik saptanmadi. Laboratuvar tetkiklerinde rutin biyokimya, hemogram, eritrosit sedimentasyon hızı (ESH), C-reaktif protein (CRP), romatoid faktör istendi. Ayrıca PA AC grafisi, 2 yönlü torakalgrafi, elektrokardiyografi (EKG) ve hassas bölgeye yönelik yüzeyel ultrasonografi (USG) istendi .Yüzeyel USG sağ sternoklaviküler eklem bölgesinde ekojenite artıșı ve ödem ile uyumlu idi. Bu sonuçlar dışında laboratuvar tetkikleri normaldi. Tetkikler sonucu TS düşünülen hastanın ağrılı ve şiş eklem bölgesine $1 \mathrm{ml}$ prilokain $+20 \mathrm{mg}$ metilprednizolon asetat (depomedrol®) karışımı ile lokal enjeksiyon uygulandı (Şekil 2). Hastanın enjeksiyon sonrası 1. hafta kontrolde ağrı ve şişliği azalmıştı. 3. ayda yapılan kontrolde ise ağrı yoktu ve sadece minimal şişlik mevcuttu.

\section{Tartışma}

Kardiyak ve özofagus kökenli göğüs ağrıları sık olmakla birlikte TS, kostokondrit, sternal sendrom, ksifoidalji gibi göğüs duvarı ağrılı sendromlarında da göğüs ağrısı görülebilmektedir (2). TS ilk kez 1921'de Alman cerrah Alexander Tietze tarafindan tanımlanmıştır. Oldukça nadir olup prevelansı tam olarak bilinmemektedir. Kesin etiyolojisi bilinmemekle birlikte Mikrotravma Teorisi üzerinde durulmaktadır. Tekrarlayan mikrotravmalar sternokostal ligamanlarda küçük yırtıklara sebep olarak hastalığa zemin hazırlayabilir. Bazen bozukluğun gelişmesinden önce kronik-aşırı öksürük, kusma, göğüse travma, viral veya bakteriyel enfeksiyonlar, otoimmün

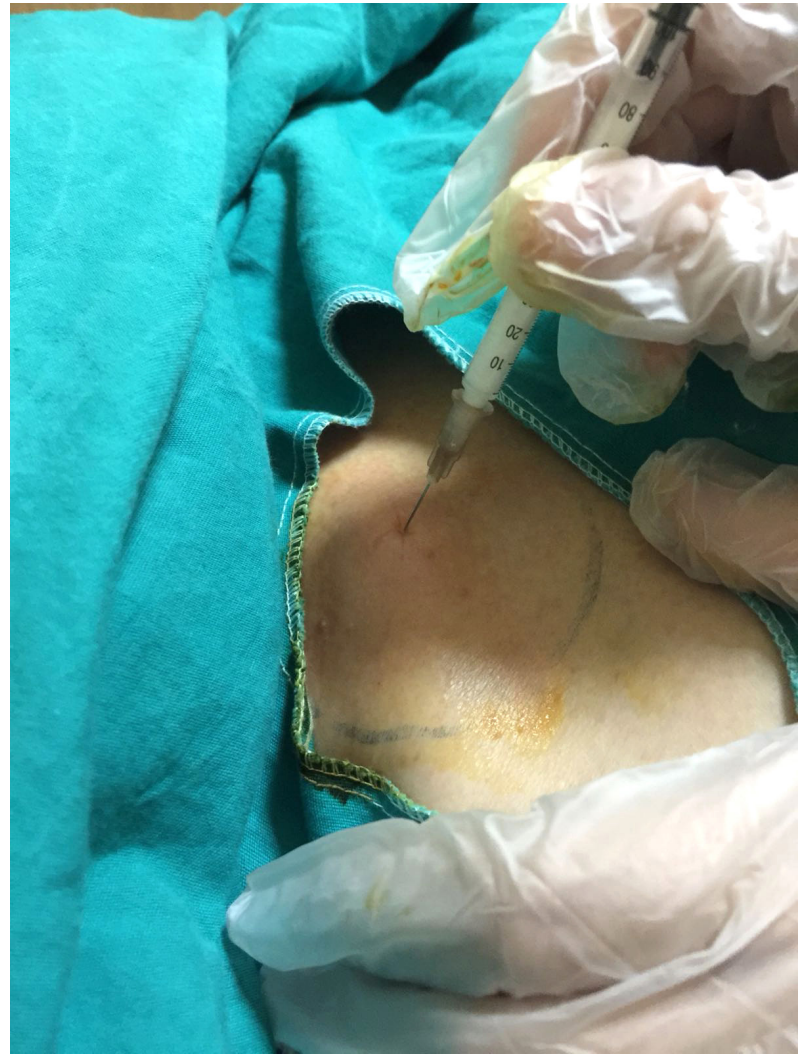

Şekil 2. Sağ sternoklaviküler ekleme lokal enjeksiyon uygulaması.

reaksiyonlar,vitamin yetersizlikleri, göğüs bölgesine ameliyat öyküsü olabilir $(1,3,4,5)$. TS hakkındaki son görüşler bu hastalığın seronegatifartritlerin bir parçası olabileceği şeklindedir. Fakat yine de bu hastalığın tek başına bir antite olarak mevcudiyeti bilinmektedir (6). Ayrıca Kumar VA. Ve Babu JN. Lomber spinal cerrahi sonrası prone pozisyona bağlı TS gelişen 40 yaş erkek hasta bildirmişlerdir (7).

Genellikle tek taraflı (\%70) olup 2-3.kostosternal eklemleri tutar ve kadınlarda daha sık görülür. Sternoklavikuler eklem tutulumu nadirdir (8). Bizim olgumuzda sadece sağ sternoklaviküler eklem tutulumu vardı. Kostosternal eklemler doğaldı. 40 yaş öncesinde daha sık görülmekle birlikte her yaşta ortaya çıabilir (1). Martino ve ark. 62 yaşında bir olgu bildirmişlerdir (9). Bizim olgumuz 72 yașındaydı. Romatoid artritte sternoklavikuler eklem tutulumu sıktır. Ancak TS seronegatif olması ve başka eklem tutulumu olmaması nedeniyle romatoid artritten ayırt edilir (6).

Hastalar tipik olarak travma öyküsü olmaksızın akut göğüs ağrısından şikayet eder. Ağrı keskindir ve omuza, kolun proksimaline yayılabilir. Radiküler ağrı eşlik edebilir. Hastanın rahatsızlığı ipsilateral kolun hareketi, gövdenin hareketi, öksürme, hapşırma ve derin nefes alıp verme ile kötüleşebilir. Tanı; anamnez, fizik muayene ve göğüs ağrisı yapan diğer hastalıkların dışlanmasına dayanır.Bu sendrom için laboratuvar sonuçları spesifik değildir. Hastanın şikayetlerinin arttığı 
dönemlerde lökositoz, CRP ve ESH artışı ve $38^{\circ} \mathrm{C}$ 'yi bulabilen ateş görülebilir (1).Akut göğüs ağrısı ile gelen tüm hastalara EKG yapılmalıdır. Biz de hastamıza akut vaka olmasa da EKG çektik ve patoloji saptamadık. USG görüntüleme, devam eden enflamatuvar süreç bölgesinde yumuşak doku şişliğini gösteren en yaygın değerlendirme yöntemidir.Ultrasonik görüntülemede lezyon bölgesi kıkırdakta kalınlık artış1 ve homojen olmayan bir ekojenite artışı görülebilir. Young JC.ve Donghwi P. USG görüntüleme ile tanı koymuş oldukları ve USG eşliğinde kortikosteroid enjeksiyonu ile tedavi etmiş oldukları TS olgusunu sunmuşlar ve TS tanı ve tedavisinde USG görüntülemenin önemini vurgulamışlardır (10). Bizde hastamıza tanıda güvenilir, ucuz olması ve radyasyon içermemesi nedeniyleUSG görüntüleme yaptırdık ve ödem ile uyumlu sonuç elde ettik. Spesifik olmamakla birlikte tanıda yararlı başka bir yöntem manyetik rezonans görüntülemedir (MRG). Komşu yağ dokusunda ve kemik iliğinde inflamasyonu gösterir (1). Bilgisayarlı tomografi (BT) tutulan eklemde hafif fokal ödem veya hafif skleroz artışı gösterebilirken, hastalık daha çok kıkırdak dokusunda ortaya çıktığ 1 için radyografiler tipik olarak normaldir. Bazı vaka raporlarında, tutulan eklemde hipermetabolik aktivitenin görüntülenmesine izin veren pozitron emisyon tomografisi CT-florodeoksiglukoz (PET/CTFDG) kullanılmıştır (11). Bu yöntem, şu anda sık kullanılmasa $\mathrm{da}$, gelecekte TS tanısında kullanılabilir. $\mathrm{Bu}$ görüntüleme yöntemleri, TS ile Kosta yapısındaki inflamatuar değişikliklerin belirgin olduğu kostokondriti ayırt etmeye yardımcı olur (1). Erken dönemde kostal kıkırdak biyopsisi ile hılı tanı konulabilir. Biyopsi sonuçları genellikle normal kartilaj dokusu şeklindedir. Bazen perikondriumda hafif ödem ve nadirende çevre dokuda nonspesifik kronik inflamasyon bulunabilir (12).

TS çeşitli kardiyak, pulmoner, nörolojik ve intraabdominal hastalıkları taklit edebilmesi nedeniyle karın ve göğüs ağrılarının ayırıcı tanısında mutlaka göz önünde bulundurulmalıdır (4).Ayrica kostosternal eklemleri tutan RA, gut, pyojenik enfeksiyonlar, tümörler ve göğüs duvarı ağrılı sendromları (kostokondit, sternal sendrom v.s) ayırıcı tanıda düşünülmesi gereken hastalıklardandır. Kostokondrit, kostokondral eklemlerin ağr1 ve hassasiyeti ile karakterize bir tablodur. TS'undan farklı olarak kartilajda şişlik yoktur, lezyonlar genellikle multipldir ve sıklıkla koroner kalp hastalıkları ile kombine olarak bulunur. Sternal sendromda ise ağrı göğüs ön duvarının tam ortasındadır. Manubriosternal eklem, sternum ve sternumu örten sternal kasta hassasiyet vardır. Semptomlar kostokondrite göre daha kronik fakat daha az şiddetlidir. Hastalık süresi değişkendir.

Tedavide birinci basamak oral veya topikal antiinflamatuvar ve analjezik ajanlardır (1). Çoğu hasta, konservatif semptomatik tedavi ile haftalar, aylar içinde ağrı ve şişlikte tam bir rahatlama yaşar. Ancak bazen hastalık alevlenmeler gösterebilir ve ağrı azalmasına rağmen şişlik uzunca bir süre devam edebilir $(4,8)$. Gerekirse fizik tedavi ajanları (lokal 1sı ve analjezik akımlar) uygulanabilir. Bu tedaviler ile rahatlama sağlanamazsa, hastalar, lokal anestezik, steroid veya her ikisi ile uygulanan lokal infiltrasyondan fayda görebilirler. Konvansiyonel tedaviye cevap vermeyen olgularda human kalsitonin denenebilir. Kronik olgularda, interkostal sinir blokları başarı ile kullanılabilir, ancak rekürrens sıktır (13). Şentürk E. ve ark. NSAIII ile proloterapiyi karşılaştıran araştırma yapmışlar ve proloterapi uygulanan hastaların NSAIII alan hastalara göre daha hızlı iyileştiklerini bildirmişlerdir. Diğer tedavi yöntemlerinin kontrendike olduğu durumlarda proloterapinin iyi bir alternatif olabileceğini bildirmişlerdir (14). İnatçı, şiddetli vakalarda tedavi seçeneği olarak kıkırdağın rezeke edildiğine dair raporlar vardır (1). Gologorsky R. ve ark. konservatif tedaviye rağmen 6 yıl boyunca şikayetleri devam eden bir olguda tutulan kaburga kıkırdağının tamamını rezeke etmişler ve kısmi kemik rezeksiyonu yaparak hasta için yüz güldürücü sonuçlar almışlardır (13). Ancak, bu genellikle tavsiye edilmez ve yalnızca duruma göre değerlendirilmelidir.

TS ile ilişkili beklenen komplikasyon yoktur. Genellikle tedaviye bağlı (enjeksiyonlar, ilaçlar veya ameliyata bağl1) komplikasyonlar görülebilir. Şikayetlerini artırabileceği ve düzelmeyi geciktirebileceği için hastalara 1-2 hafta boyunca yorucu aktivitelerden kaçınmaları tavsiye edilmelidir. Hastanın fiziksel rahatsızlığını, hastalığın hasta üzerinde bıraktığı psikolojik etkiyi, boşa harcanan zamanı ve masrafları azaltmak için, aile hekimleri, pratisyen hekimler, FTR, Kulak Burun Boğaz, Göğüs Hastalıkları hekimleri başta olmak üzere tüm hekimler bu klinik durumun farkında olmalı ve durumu tanımalıdır (11).

Peer-review: Externally peer-reviewed.

Informed Consent: Informed consent was obtained from the volunteer participants.

Author Contributions: Concept - HÖD, HRE; Design - HÖD, HRE; Supervision - HÖD, HRE; Resource - HÖD, HRE; Materials - HÖD, HRE; Data Collection and/ or Processing - HÖD, HRE; Analysis and/or Interpretation - HÖD, HRE; Literature Search - HÖD, HRE; Writing - HÖD, HRE; Critical Reviews - HÖD, HRE.

Conflict of Interest: The authors do not have any conflicts of interest.

Financial Disclosure: The authors declared that this study has received no financial support.

Hakem Değerlendirmesi: Dış Bağımsız.

Hasta Onamı: Gönüllü katılımcılardan bilgilendirilmiş onam alınmıştır.

Yazar Katkıları: Fikir - HÖD, HRE; Tasarım - HÖD, HRE; Denetleme - HÖD, HRE; Kaynaklar - HÖD, HRE; Malzemeler- HÖD, HRE; Veri Toplanması ve/veya Işlemesi -HÖD, HRE; Analiz ve/veya Yorum - HÖD, HRE; Literatür Taraması - HÖD, HRE; Yazıyı Yazan HÖD, HRE; Eleştirel İnceleme - HÖD, HRE.

Çıkar Çatışması: Yazarların herhangi bir çıkar çatışması bulunmamaktadır.

Finansal Destek: Yazarlar bu çalışma için finansal destek almadıklarını beyan etmişlerdir

\section{Kaynaklar}

1. Rokicki W, Rokicki M, Rydel M. What do we know about Tietze's syndrome? Kardiochir Torakochirurgia Pol. 2018; 15:180-182. [crossref]

2. Semble EL, Wise C. Chest Pain: A rheumatologist's perspective. South Med J 1988; 81:64-68. [crossref]

3. Gregory PL, Biswas AC, Batt ME. Musculo skeletal problems of the chestwall in athletes. Sports Med. 2002;32:235-50. 
4. Boehme MWJ, Scherbaum WA, Pfeiffer EF. Tietze's syndrome - a chameleon under the thoracic abdominal pain syndroms. Clin Wochenschr 1988; 66: 11421145. [crossref]

5. Giovanni R. Effects of human calsitonin on pain in the treatment of Tietze's Syndrome. Clin Ther. 1985; 7:669-673. PMID: 4075361

6. Aeschlimann A, Kahn MF. Tietze's syndrome: a critical review. Clin Exp Rheumatol. 1990; 8:407-412. PMID: 1697801

7. Kumar VA, Babu JN. Refractory Tietze's syndrome occurring after lumbar spine surgery in prone position. Indian J Orthop. 2019; 53:574-577. [crossref]

8. Fam AG. Smythe HA. Musculoskeletal Chest Wall Pain. Can Med Assoc 1985; 133:379-389. PMID: 4027804

9. Do W et al. Atypical Tietze's Syndrome Misdiagnosed as Atypical Chest Pain: Letter to the Editor. Pain Med. 2018 ;19:813-815. [crossref]
10. Cho JY, Park D. Ultrasound-Guided corticosteroid injection in a patient with Tietze syndrome combined with costochondral joint swelling. Am J Phys Med Rehabil. 2019; 98:71-73. [crossref]

11. Rosenberg M, Conermann T.TietzeSyndrome. Stat Pearls Publishing LLC Bookshelf ID: NBK564363, PMID: 33232033. October 21, 2020.

12. Pinals RS. Traumatic Arthritis and Allied Conditions. In: McCarty DJ Hollander JL. eds. Arthritis and Allied Conditions. Philadelphia: WB Saunders. 1989: 626.

13. Gologorsky R, Hornik B, Velotta J. Surgical management of medically refractory Tietze syndrome. Ann Thorac Surg. 2017; 104:443-445. [crossref]

14. Şentürk E, Şahin E, Serter S. Prolotherapy: An effective therapy for Tietze syndrome. J Back Musculoskelet Rehabil. 2017; 30:975-978. [crossref] 